Review Article

\title{
The Practice of Nursing in the Prevention and Control of Postpartum Hemorrhage: An Integrative Review
}

\author{
Haimee Emerich Lentz Martins ${ }^{1}$, Maria de Lourdes de Souza ${ }^{2}$, Sabiha Khanum ${ }^{3}$, Najma Naz $^{3}$, \\ Anna Carolina Raduenz Huf Souza ${ }^{3}$ \\ ${ }^{1}$ Public Health Department of Santa Catarina (SES-SC), Florianópolis, Santa Catarina, Brazil \\ ${ }^{2}$ Post Graduation Program in Nursing (PEN/UFSC) and REPENSUL Institute, Federal University of Santa Catarina (UFSC), Florianópolis, \\ Santa Catarina, Brazil \\ ${ }^{3}$ Post Graduation Program in Nursing from Federal University of Santa Catarina (PEN/UFSC), Florianópolis, Santa Catarina, Brazil
}

\section{Email address:}

haimeelentz@hotmail.com (H. E. L. Martins), repensul@uol.com.br (M. d. L. d. Souza ), sabihakhanum@hotmail.com (S. Khanum), najma.sayyed@live.com (N. Naz), acrhuf@gmail.com (A. C. R. H. Souza)

\section{To cite this article:}

Haimee Emerich Lentz Martins, Maria de Lourdes de Souza, Sabiha Khanum, Najma Naz, Anna Carolina Raduenz Huf Souza. The Practice of Nursing in the Prevention and Control of Postpartum Hemorrhage: An Integrative Review. American Journal of Nursing Science.

Vol. 5, No. 1, 2016, pp. 8-15. doi: 10.11648/j.ajns.20160501.12

\begin{abstract}
The study was developed to identify and analyze nursing practices in the literature related to the prevention and control of postpartum hemorrhage. Integrative review of on-line articles indexed in the databases MedLine, PubMed, Lilacs, SciELO, Embase, CINAHL and Web of Science (in the period between September 2013 and February 2014); search strategies by keywords and mesh descriptors were used. The 22 studies selected were categorized as: 1. Implementation of the active handling of the third stage of the delivery; 2. Use of Misoprostol; 3. Blood loss estimate; 4. Nursing training on the handling of postpartum hemorrhage; 5. Other handling measures to prevent postpartum hemorrhage; and 6. Use of technology to record data on postpartum hemorrhage. The present integrative review revealed that nursing professionals (midwives, nurses, traditional birth attendants), together with other professionals, have contributed to implement the active handling of the third stage of the labor, and to elaborate and implement protocols, trainings and assessments of results of this practice in the services. Despite the global recommendations to adopt the active management of third stage of labor, whenever a qualified professional delivers such care, this practice is still not broadly developed and implemented, even in the reference hospitals in Brazil and many other countries.
\end{abstract}

Keywords: Nursing, Postpartum Hemorrhage, Prevention

\section{Introduction}

The postpartum hemorrhage (PPH) is an obstetric emergency associated with both the vaginal birth and cesarean section. $\mathrm{PPH}$ and hypertensive disorders of pregnancy are the leading causes of maternal morbidity and mortality in developing countries. Bleeding is the main cause of maternal death in Africa (33.9\%) and Asia (30.8\%) and second cause in Latin America and in the Caribbean (20.8\%) [1]. globally, 35\% of maternal deaths are associated with PPH [2].

The estimated mortality rate from bleeding in developed countries was below 13.4\% [1]. However, studies have shown the trend of increased incidence of PPH as a cause of severe maternal morbidity (near miss) in developed countries, such as Australia, Canada, United Kingdom and United States [3]. Similarly, 3179 maternal deaths $(14.26 \%$ of the total) were related to hemorrhage from 1997 to 2009 according to mortality information system of the Ministry of health in Brazil [4]. Of these 1296 (40.8\%) deaths occurred after childbirth.

World Health Organization (WHO) defines PPH as $500 \mathrm{ml}$ of blood loss after vaginal birth and $1000 \mathrm{ml}$ of blood loss in case of cesarean births. The bleeding that occurs during the first 24 hours after delivery is called primary hemorrhage. When this occurs after 24 hours of birth until six weeks it is called secondary postpartum hemorrhage [3].

Around $80 \%$ of women's deaths occur due to primary hemorrhage which is associated with excessive bleeding in the 
early 24 hours after child birth. Uterine atony is the main cause of primary hemorrhage. Other causes are retained placenta, birth canal lacerations or perineum, uterine rupture, uterine inversion, and coagulation disorders $[5,6]$.

Prevention and control of PPH and its adverse results, has been highlighted as a key point in the literature, in guidelines and documents of International Federation of Gynecology and Obstetrics (FIGO), and training of health professionals and midwives, for proper management of the third stage of labor $[2,3,7]$.

WHO considers the active management of the third stage of labor as the main intervention for prevention and consequent reduction of maternal deaths by hemorrhage, taking into consideration the clinical evidence [1].

The active management of the third stage of labor involves interventions to promote the expulsion of the placenta and the uterine contraction with the intention of preventing or reducing blood loss. The interventions include use of Uterotonic, controlled cord traction and uterine massage. Other interventions related to prevention of postpartum hemorrhage are being studied, such as skin-to-skin contact, breastfeeding, early cord clamping time [8]. It was therefore necessary to identify and analyze better nursing practices used for prevention and control of PPH.

\section{Materials and Methods}

\subsection{Search Strategies and Sources}

A systematic search was conducted from September 2013 to February 2014 to answer the following question: What are the nursing practices used for the prevention and control of postpartum hemorrhage? We consulted electronic databases of MEDLINE, PubMed, Lilacs, SciELO, Embase, CINAHL and Web of Science to search for studies on nursing practices for prevention and control of PPH. The search strategy was based on a number of medical subject headings (MESH) keywords and descriptors as shown in Table 1.

Table 1. Search strategy used to identify reference studies on nursing practices for prevention and control of PPH in the world.

\begin{tabular}{ll}
\hline Category & Search terms \\
\hline MESH Keywords & $\begin{array}{l}\text { "post-partum hemorrhage" OR "post partum } \\
\text { hemorrhage" OR "postpartum hemorrhage" OR } \\
\text { and Descriptors }\end{array}$ \\
& "post-partum haemorrhage" OR "post partum \\
haemorrhage" OR "postpartum haemorrhage" & nursing OR midwife* OR midwive*, nursing AND \\
Keywords & intervention, nursing AND care, technolog* AND \\
& nursing, nursing AND prevent*, nursing AND care \\
\hline
\end{tabular}

There was no search restriction regarding the period of publication in order to include as many articles as possible on this theme. The filter activated for the language of searched studies was English and for type of study were controlled trials, meta-analyses, randomized clinical studies, multicenter trials, reviews, systematic reviews, cohort studies, case-control and other experimental and observational studies. Articles were classified [9] as defined in Table 2.
Table 2. Classification of studies based on Melnyk and Fineout-Overholt [9].

\begin{tabular}{ll}
\hline Level & Description \\
\hline I & $\begin{array}{l}\text { Evidence from systematic review or meta-analysis of all relevant } \\
\text { randomized controlled trials or from clinical guidelines based on } \\
\text { systematic reviews of randomized controlled clinical trials }\end{array}$ \\
& $\begin{array}{l}\text { Evidence derived from at least one randomized controlled } \\
\text { well-designed trial }\end{array}$ \\
II & $\begin{array}{l}\text { Evidence obtained from well-designed clinical trials without } \\
\text { randomization }\end{array}$ \\
III & $\begin{array}{l}\text { Evidence from well-designed cohort studies and case-control } \\
\text { Studies }\end{array}$ \\
V & $\begin{array}{l}\text { Evidence from systematic review of descriptive and qualitative } \\
\text { studies }\end{array}$ \\
VI & $\begin{array}{l}\text { Evidence derived from a single descriptive or qualitative study } \\
\text { Evidence from opinion of authorities and/or expert committees } \\
\text { VII }\end{array}$ \\
\hline
\end{tabular}

\subsection{Selection Criteria}

A total of 2774 articles were initially identified using the search criteria from all the electronic databases, of which 382 were duplicated. The titles screening of the remaining 2392 articles resulted in 266 relevant articles being selected for abstract screening. The abstracts of these 266 papers were then examined resulting in 36 papers being examined in full. Of these, 14 were excluded after reading the full texts. The remaining 22 studies were fully read, quality assessed and included in the review (Figure 1). Screening of each article was done by two independent reviewers and disagreement between them was resolved by discussion.

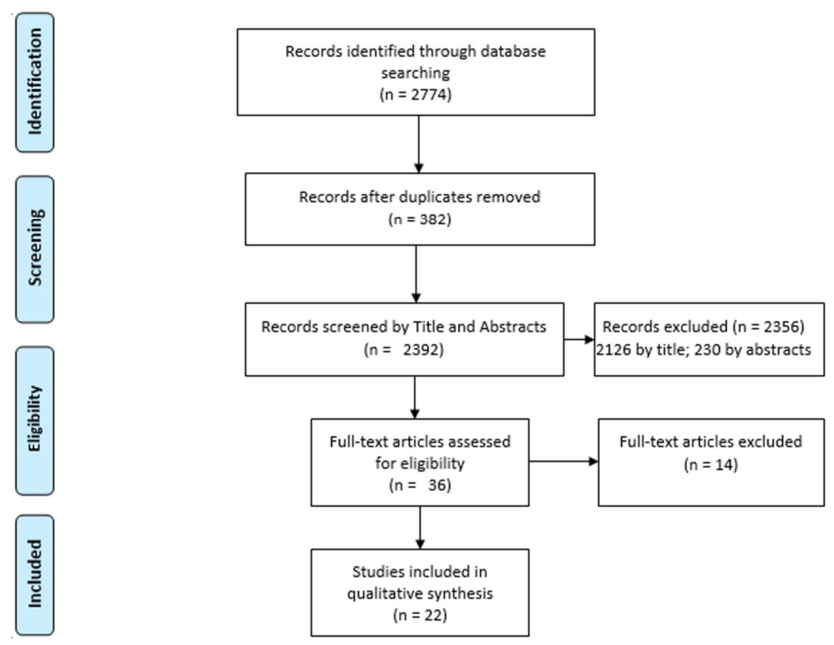

Figure 1. Flow chart of process and criteria used in the literature review selection of twenty two studies on nursing practices for prevention and control of PPH in world.

\subsection{Analysis}

All 22 studies were fully read and the following information was abstracted from them. (a) General information like authors, journal, publication date, country and language. (b) Research design, location, participants, and aim. (c) Sampling method and sample size. (d) Nursing practice used for prevention and control of PPH. (e) Results and conclusions. Six categories of nursing practice have been identified for the prevention and control of $\mathrm{PPH}$. The review results are 
presented according to these categories.

\section{Results}

Among the 22 included studies, 16 were quantitative and 5 were qualitative studies and one study used mixed method. 11 of the studies were conducted in rural areas, 6 in hospitals, 2 in health centers, 2 in universities and one was a postal survey covering a whole country. The included 22 studies were conducted and based in regions shown in Table 3 while characteristics of these 22 articles are summarized in Table 4.

Table 3. Region where the selected 22 studies were based in the world.

\begin{tabular}{ll}
\hline Region & Number of studies \\
\hline Asia & 7 \\
Africa & 6 \\
Central America & 3 \\
Oceania & 2 \\
South America & 2 \\
Europe & 1 \\
North America & 1 \\
\hline
\end{tabular}

Table 4. Characteristics of 22 studies on nursing practices for prevention and control of PPH worldwide.

\begin{tabular}{|c|c|c|c|c|}
\hline Title/Ref & Location/Year & Objectives & Study design & Nursing practice \\
\hline $\begin{array}{l}\text { Early suckling and postpartum } \\
\text { haemorrhage: controlled trial in } \\
\text { deliveries by traditional birth } \\
\text { attendants [10] }\end{array}$ & Malawi/1989 & $\begin{array}{l}\text { To assess whether breastfeeding } \\
\text { immediatelyafter childbirth reduces the } \\
\text { frequency of PPH and the frequency of } \\
\text { placenta retention }\end{array}$ & $\begin{array}{l}\text { Randomized controlled } \\
\text { trial (RCT) - Level II }\end{array}$ & $\begin{array}{l}\text { Other PPH } \\
\text { management } \\
\text { strategies }\end{array}$ \\
\hline $\begin{array}{l}\text { Knowledge, attitudes and practices of } \\
\text { trained traditional birth attendants in } \\
\text { the Gambia in the prevention, } \\
\text { recognition and management of } \\
\text { postpartum haemorrhage [11] }\end{array}$ & Gambia/2002 & $\begin{array}{l}\text { To evaluate the knowledge, attitudes and } \\
\text { practices of trained traditional birth } \\
\text { attendants in the prevention, recognition } \\
\text { and management of PPH }\end{array}$ & $\begin{array}{l}\text { Descriptive Qualitative } \\
\text { study - Level VI }\end{array}$ & $\begin{array}{l}\text { Training programs } \\
\text { for handling PPH }\end{array}$ \\
\hline $\begin{array}{l}\text { Blood loss at delivery: how accurate is } \\
\text { your estimation? [12] }\end{array}$ & Australia/2003 & $\begin{array}{l}\text { To identify estimates of blood loss by } \\
\text { doctors and nurses through simulation }\end{array}$ & $\begin{array}{l}\text { Descriptive Quantitative } \\
\text { study - Level VI }\end{array}$ & $\begin{array}{l}\text { Estimated blood } \\
\text { loss }\end{array}$ \\
\hline $\begin{array}{l}\text { Oral misoprostol for prevention of } \\
\text { postpartum hemorrhage by } \\
\text { paramedical workers in India [13] }\end{array}$ & India/2006 & $\begin{array}{l}\text { To identify the ability of trained } \\
\text { paramedics in active management of the } \\
\text { third Stage of labor (AMTSL) and } \\
\text { misoprostol }\end{array}$ & RCT - Level II & Use of misoprostol \\
\hline $\begin{array}{l}\text { Decision making by auxiliary nurses to } \\
\text { assess postpartum bleeding in a } \\
\text { Dominican Republic maternity ward } \\
\text { [14] }\end{array}$ & $\begin{array}{l}\text { Republica } \\
\text { Dominicana /2006 }\end{array}$ & $\begin{array}{l}\text { To understand the process of } \\
\text { decision-making nursing assistants use in } \\
\text { estimating postpartum bleeding }\end{array}$ & $\begin{array}{l}\text { Qualitative Ethnography } \\
\text { /observation - Level VI }\end{array}$ & $\begin{array}{l}\text { Estimated blood } \\
\text { loss }\end{array}$ \\
\hline $\begin{array}{l}\text { Reducing postpartum hemorrhage in } \\
\text { Vietnam: assessing the effectiveness } \\
\text { of active management of third-stage } \\
\text { labor [15] }\end{array}$ & Vietnam/2006 & $\begin{array}{l}\text { To evaluate active management of third } \\
\text { stage of labor with the use of oxytocin in } \\
\text { low resources countries. }\end{array}$ & $\begin{array}{l}\text { Quasi-experimental } \\
\text { study - Level III }\end{array}$ & AMTSL \\
\hline $\begin{array}{l}\text { Estimating blood loss after birth: using } \\
\text { simulated clinical examples [16] }\end{array}$ & Australia/2007 & $\begin{array}{l}\text { To identify the accuracy of estimated } \\
\text { blood loss through simulation }\end{array}$ & $\begin{array}{l}\text { Descriptive Quantitative } \\
\text { study - Level VI }\end{array}$ & $\begin{array}{l}\text { Estimated blood } \\
\text { loss }\end{array}$ \\
\hline $\begin{array}{l}\text { Evoking the guardian angel: childbirth } \\
\text { care in a Palestinian hospital [17] }\end{array}$ & Palestine/2007 & $\begin{array}{l}\text { To evaluate the quality of care of a } \\
\text { maternity ward in Palestine }\end{array}$ & $\begin{array}{l}\text { Qualitative study - Level } \\
\text { VI }\end{array}$ & $\begin{array}{l}\text { Training programs } \\
\text { for handling PPH }\end{array}$ \\
\hline $\begin{array}{l}\text { Variation in the postpartum } \\
\text { hemorrhage rate in a clinical trial of } \\
\text { oral misoprostol [18] }\end{array}$ & India/2008 & $\begin{array}{l}\text { To identify the factors associated with } \\
\text { variation to PPH using oral misoprostol }\end{array}$ & RCT - Level II & Use of misoprostol \\
\hline $\begin{array}{l}\text { Postpartum hemorrhage prevention: a } \\
\text { case study in northern rural Honduras } \\
{[19]}\end{array}$ & Honduras/2008 & $\begin{array}{l}\text { To investigate the relationship between } \\
\text { the blood loss after-birth and the third } \\
\text { stage management }\end{array}$ & $\begin{array}{l}\text { Descriptive-Quantitative } \\
\text { study - Level VI }\end{array}$ & AMTSL \\
\hline $\begin{array}{l}\text { Prevention of postpartum hemorrhage: } \\
\text { options for home births in rural } \\
\text { Ethiopia [20] }\end{array}$ & Ethiopia/2009 & $\begin{array}{l}\text { To evaluate the safety of misoprostol for } \\
\text { PPH in home births attended by } \\
\text { traditional birth attendants (TBAs) }\end{array}$ & RCT - Level III & Use of misoprostol \\
\hline $\begin{array}{l}\text { Risk factors for postpartum } \\
\text { hemorrhage in vaginal deliveries in a } \\
\text { Latin-American population [21] }\end{array}$ & $\begin{array}{l}\text { Argentina and } \\
\text { Uruguay/2009 }\end{array}$ & $\begin{array}{l}\text { To identify the risk factors for immediate } \\
\text { postpartum hemorrhage after vaginal } \\
\text { delivery }\end{array}$ & $\begin{array}{l}\text { Prospective cohort study } \\
\text { - Level IV }\end{array}$ & $\begin{array}{l}\text { Estimated blood } \\
\text { loss }\end{array}$ \\
\hline $\begin{array}{l}\text { Active versus expectant management } \\
\text { of the third stage of labor and } \\
\text { implementation of a protocol [22] }\end{array}$ & $\begin{array}{l}\text { United State of } \\
\text { America/2010 }\end{array}$ & $\begin{array}{l}\text { To assess the adoption of Active } \\
\text { Management Protocol for PPH in a large } \\
\text { tertiary hospital and evaluate the results }\end{array}$ & $\begin{array}{l}\text { Descriptive } \\
\text { Quanti-qualitative } \\
\text { service evaluation study } \\
\text { - Level VI }\end{array}$ & AMTSL \\
\hline $\begin{array}{l}\text { Comparison of excessive postpartum } \\
\text { blood loss estimates among three } \\
\text { subgroups of women attending births } \\
\text { in Matlab, Bangladesh [23] }\end{array}$ & Bangladesh/2010 & $\begin{array}{l}\text { To assess and compare the thresholds for } \\
\text { excessive postpartum blood loss }\end{array}$ & $\begin{array}{l}\text { Descriptive-Quantitative } \\
\text { study - Level VI }\end{array}$ & $\begin{array}{l}\text { Estimated blood } \\
\text { loss }\end{array}$ \\
\hline $\begin{array}{l}\text { Care during the third stage of labor: a } \\
\text { postal survey of UK midwives and } \\
\text { obstetricians [24] }\end{array}$ & $\begin{array}{l}\text { United } \\
\text { Kingdom/2010 }\end{array}$ & $\begin{array}{l}\text { To identify the routine practice for the } \\
\text { management of the third stage of labor }\end{array}$ & Postal survey - Level VI & AMTSL \\
\hline $\begin{array}{l}\text { Administration of misoprostol by } \\
\text { trained traditional birth attendants to } \\
\text { prevent postpartum haemorrhage in }\end{array}$ & Pakistan/2010 & $\begin{array}{l}\text { To determine whether misoprostol is safe } \\
\text { and efficacious in preventing PPH when } \\
\text { administered by trained traditional birth }\end{array}$ & RCT - Level II & Use of misoprostol \\
\hline
\end{tabular}




\begin{tabular}{|c|c|c|c|c|}
\hline Title/Ref & Location/Year & Objectives & Study design & Nursing practice \\
\hline $\begin{array}{l}\text { homebirths in Pakistan: a randomized } \\
\text { placebo-controlled trial [25] }\end{array}$ & & attendants (TBA) at home & & \\
\hline $\begin{array}{l}\text { Prevention of postpartum hemorrhage } \\
\text { at home birth in Afghanistan [26] }\end{array}$ & Afghanistan/2010 & $\begin{array}{l}\text { To test the effectiveness of } \\
\text { community-based education and } \\
\text { distribution of misoprostol for } \\
\text { prevention of PPH }\end{array}$ & $\begin{array}{l}\text { Experimental study, not } \\
\text { controlled - Level III }\end{array}$ & Use of misoprostol \\
\hline $\begin{array}{l}\text { Integration of the practice of active } \\
\text { management of the third stage of labor } \\
\text { within training and service } \\
\text { implementation programming in } \\
\text { Zambia [27] }\end{array}$ & Zambia/2010 & $\begin{array}{l}\text { To evaluate Active Management } \\
\text { Protocol by midwives in clinical practice } \\
\text { and identify barriers in its } \\
\text { implementation }\end{array}$ & $\begin{array}{l}\text { Quantitative Descriptive } \\
\text { study - Level VI }\end{array}$ & AMTSL \\
\hline $\begin{array}{l}\text { Using Uniject to increase the use of } \\
\text { prophylactic oxytocin for management } \\
\text { of the third stage of labor in Latin } \\
\text { America [28] }\end{array}$ & Argentina/2010 & $\begin{array}{l}\text { To evaluate the effectiveness of the use } \\
\text { of oxytocin by health providers in small } \\
\text { maternity homes }\end{array}$ & $\begin{array}{l}\text { Randomized, not } \\
\text { controlled - Level III }\end{array}$ & AMTSL \\
\hline $\begin{array}{l}\text { Using cell phones to collect } \\
\text { postpartum hemorrhage outcome data } \\
\text { in rural Ghana [29] }\end{array}$ & Ghana/2011 & $\begin{array}{l}\text { To evaluate the use of mobile phones by } \\
\text { professionals and traditional midwives in } \\
\text { report of bleeding after childbirth }\end{array}$ & $\begin{array}{l}\text { Descriptive-Qualitative } \\
\text { study - Level VI }\end{array}$ & Use of technology \\
\hline $\begin{array}{l}\text { Two-provider technique for bimanual } \\
\text { uterine compression to control } \\
\text { postpartum hemorrhage [30] }\end{array}$ & Ghana/2012 & $\begin{array}{l}\text { To analyze the impact of bimanual } \\
\text { uterine compression in the management } \\
\text { of bleeding }\end{array}$ & $\begin{array}{l}\text { Descriptive-Quantitative } \\
\text { study - Level VI }\end{array}$ & $\begin{array}{l}\text { Other PPH } \\
\text { management } \\
\text { strategies }\end{array}$ \\
\hline $\begin{array}{l}\text { Teaching Guatemala midwives about } \\
\text { postpartum hemorrhage [31] }\end{array}$ & Guatemala/2012 & $\begin{array}{l}\text { To evaluate the effect of a culturally } \\
\text { sensitive teaching unit on traditional } \\
\text { midwives' knowledge in preventing PPH }\end{array}$ & $\begin{array}{l}\text { Quasi-experimental } \\
\text { study - Level III }\end{array}$ & $\begin{array}{l}\text { Training programs } \\
\text { for handling PPH }\end{array}$ \\
\hline
\end{tabular}

\subsection{Active Management of the Third Stage of Labor (AMTSL)}

This category includes six articles, of which, two were quasi-experiments, two cross-sectional descriptive studies, one postal survey and one protocol evaluation study.

In USA, the Department of Public Health of Illinois, Chicago, and the Obstetric Safety Commission of a tertiary hospital considered AMTSL beneficial when compared with expectant management, based on the reduction rate of the $\mathrm{PPH}$ [22]. The overall rate of PPH decreased from $4.52 \%$ to $4.21 \%$.

A postal survey (questionnaire) was conducted in UK to ask about care during the third stage of labor, for vaginal and cesarean births [24]. Most physicians (93\%) and nurses (73\%) reported the use of AMTSL in vaginal birth. The syntometrine (oxytocin and ergometrine) was the Uterotonic of choice in vaginal birth and was used by $86 \%$ of nurses, and $79 \%$ of the doctors.

A quasi-experimental study was conducted in Argentina to evaluate the effectiveness of AMTSL and the use of oxytocin using the Uniject device [28]. They observed that the average rate of prophylactic use of oxytocin increased from $14.6 \%$ before the intervention to $85.6 \%$ of births. $96 \%$ of the professionals reported that this device facilitated administration of oxytocin. The practice of controlled cord traction increased from $7 \%$ to $47.8 \%$, and uterine massage from $6.3 \%$ to $48.9 \%$.

In a descriptive cross-sectional study [19] conducted in Honduras, nursing staff was trained to estimate blood loss and to manage PPH. There was no significant correlation between PPH management techniques and Estimated Blood Loss (EBL), $(\mathrm{r}=.060 ; \mathrm{p}=.368)$. There was a statistically significant $(\mathrm{p}<.001)$ correlation between oxytocin administration and lower EBL $(\mathrm{r}=-.232)$. There was less blood loss associated with the use of oxytocin and routine use of Uterotonic agent appears beneficial.

In a quasi-experimental study [15] conducted in Vietnam for low resource setting AMTSL was associated with a $34 \%$ reduction in PPH incidence (of which $30 \%$ due to uterine atony), reducing the time of the third stage in addition to 30 minutes $(80 \%)$, reducing the additional use of oxytocin $(40 \%)$ and reducing the need for bimanual compression (40\%).

In Zambia, 62 midwives were interviewed, and 82 observations were made on the practice and training of AMTSL [27]. Only one third of the respondents indicated the knowledge of uterine massage as a component of Active Management Protocol. During the observation of deliveries it was found that the oxytocin was the first choice of Uterotonic (70 of 82). Most women $(\mathrm{n}=48 ; 58.5 \%)$ only received a single injection of Uterotonic. Twenty-five births $(40.4 \%)$ were carried out in accordance with all the elements and terms of active management protocol currently recommended in the country.

\subsection{Use of Misoprostol}

In Afghanistan, a non-randomized study was conducted to test the safety, feasibility and acceptance of misoprostol for the prevention of $\mathrm{PPH}$ in the households in a rural community [26]. The sample included 3187 women of which 2039 in the intervention group and 1148 in the comparison group. Of the 1421 women in the intervention group who took misoprostol, $100 \%$ correctly took it after birth. Adverse effect rates were also lower in the intervention group. $92 \%$ of the women in the intervention group were willing to use misoprostol in their next pregnancy.

In Ethiopia, traditional birth attendants were trained to administer $600 \mathrm{mcg}$ of oral misoprostol to test the safety and feasibility of home-based prophylaxis of PPH [20]. Of the 966 vaginal deliveries, only $8.9 \%$ of those who took misoprostol $(n=485)$ needed additional intervention due to excessive bleeding compared to $18.9 \%$ of those who did not take 
misoprostol $(n=481)$. This study confirms the use of misoprostol in home births to be safe if administered correctly by trained community health care workers.

A study based on 1200 women (50\% in each group) in India was conducted to test $600 \mathrm{mcg}$ of oral misoprostol in intervention group and current government guidelines (with intramuscular methergine and methergine tablet after expulsion of the placenta) for comparison group (13). There was a significant reduction in duration of the third stage of labor $(7.9+/-4.2 \mathrm{~min}$ vs. $10.9+/-4.3 \mathrm{~min} ; \mathrm{p}<.001)$, and in median blood loss in the intervention group $(100 \mathrm{ml}$ vs $200 \mathrm{ml})$ Overall, a low incidence of PPH was observed $(<1 \%)$ in both groups. Similarly in another randomized clinical trial conducted in India, the misoprostol group (812 vs 808 in placebo) had significantly lower probability of having a PPH [18]. However, the authors also noted a reduction in the rate of $\mathrm{PPH}$ in the placebo group over the course of time. This suggests that reduction in PPH was associated with improved skills and delivery practices of midwives that decreased duration of the second stage of labor.

Oral misoprostol $(600 \mathrm{mcg})$ has also been found useful in a randomized, double-blind, placebo-controlled trial conducted in Pakistan, when administered by trained traditional birth attendants at home deliveries [25]. Misoprostol was associated with significant reduction (24\%) in the rate of PPH $(\geq 500 \mathrm{ml})$ (16.5\% versus $21.9 \%$; relative risk $0.76,95 \%$ CI $0.59-0.97$ ). Shivering and chills were significantly more common with misoprostol and no maternal deaths among participants.

\subsection{Estimated Blood Loss (EBL)}

There were few studies on the accurate estimation of blood loss during childbirth in books and periodicals and about how the midwives learn to EBL during childbirth. A study conducted in Australia identified the underestimation of blood loss by $30-50 \%$ and recommends that the EBL should be included in training curricula in obstetrics [12]. This study suggests for patient safety, to double the estimates of blood loss at birth when it is considered above $500 \mathrm{ml}$. Similarly in another study conducted in Australia, the estimation of blood loss in a container was more accurate than blood estimation on sanitary pads or clothing [16]. Improvements are still needed in visual estimation of blood loss after childbirth through educational and training programs.

In the Dominican Republic was conducted a qualitative ethnographic study to evaluate the postpartum bleeding in women [14]. A questionnaire was designed to predict the decision making process of 24 auxiliary nurses. The study found that these professionals were aware of the importance of monitoring blood volume over time, assess the response to uterine massage and identify signs of shock. Even with lack of routine, systematic assessment of blood loss is conducted on every woman.

Another study conducted in Bangladesh assessed the excessive blood loss after delivery reported by 37 traditional birth attendants, 14 skilled birth attendants and 98 laywomen [23]. There were significant differences in assessment of blood loss among the groups. Thresholds for excessive blood loss estimated by laywomen and TBAs exceed biomedical standards for PPH. The knowledge of the skill of birth attendants (SBAs) about excessive bleeding corresponded to the biomedical definition of severe PPH (>1000 ml). They concluded that the lack of accurate measurement of blood loss can result in an increase in the maternal morbidity and mortality.

Estimation of blood loss is shown to have improved in a prospective cohort study conducted in Argentina and Uruguay where a transparent plastic bag was used for blood collection placed under the buttocks after child birth [21]. The collected blood was placed in a calibrated bottle and recorded by midwives and nurses. The average blood loss was $215 \mathrm{ml}$, and the median was of $150 \mathrm{ml}$. Overall, $10.8 \%$ had moderate postpartum hemorrhage and $1.9 \%$ had severe postpartum hemorrhage. The study suggests that many of the risk factors for early postpartum hemorrhage are related to complications of the second and third stage of labor.

\subsection{Training Programs for Handling PPH}

A qualitative descriptive study was conducted in Gambia to evaluate the knowledge and practices of midwives in the prevention and management of $\mathrm{PPH}$ [11]. Semi-structured interviews were conducted for 22 midwives. The midwives knew complications such as retained placenta and excessive blood loss and were well aware of the need to refer women to a health facility quickly. However they were not trained on the causes of excessive blood loss. The study suggests improving the skills of all health workers in primary care to reduce PPH at home childbirth.

A descriptive-qualitative study was designed to evaluate the quality of maternity care in a large, public, referral hospital in Palestinian [17]. Semi-structured questionnaire was used on 9 midwives, 14 nurses and 8 doctors, about their job description, responsibilities, practices, perceived barriers, and training needs, etc. Doctors and midwives have reported high levels of stress. For midwives, this stress is due to working conditions, low wages, lack of personnel and lack of support and supervision. For doctors and obstetrician, stress is related to the lack of experience with complicated cases in emergencies, for which they were unprepared. Magnesium sulfate was not used for pre-eclampsia or eclampsia, and PPH was a frequent occurrence. Inappropriate practices were observed at the time of delivery such as: routine use of intravenous oxytocin during childbirth, lack of family support, little use of AMTSL, use of routine episiotomy, inappropriate and insufficient supervision and lack of skills.

A quasi-experimental and qualitative Study was conducted in Guatemala to evaluate the effect of training on the knowledge of traditional midwives to prevent and treat postpartum hemorrhage [31]. Sixteen midwives participated in a 1-day training program. Pre-test and post-test was used with PPH Behavioral Checklist from the American College of Nurse Midwives (ACNM) to assess and compare knowledge of PPH interventions before and after training. The score in the pretest was 1.385 rising to 4.846 in the post-test. The raw test scores were indicative of a strong significance of educational intervention in increasing knowledge of midwives. 


\subsection{Other PPH Management Strategies}

Two studies were selected in this category; the first is a descriptive and quantitative study conducted in Ghana and the second a randomized controlled study conducted in Malawi. The aim of the study conducted in Ghana was to analyze the impact of team-based bimanual uterine compression for managing postpartum hemorrhage from uterine atony [30]. One participant performed external compression on the fundus with both hands and another realized internal pressure against the body of the uterus with a single hand. Individual participants were unable to compress the entire uterus and keep the compression for more than two and a half minutes without getting tired. As a team, the participants were able to compress the entire uterus and keep the compression for 5 minutes. Results suggest that bimanual uterine compression is more effective when performed by a team.

The second study [10] was conducted in Malawi in order to evaluate whether breastfeeding immediately after birth reduces the frequency of $\mathrm{PPH}$, the mean blood loss, and the frequency of retained placenta. 23 TBAs in suckling group recorded blood loss in 2104 deliveries and 26 in control group recorded blood loss in 2123 deliveries. The frequency of PPH ( $>500 \mathrm{ml}$ ) was $7.9 \%$ in the suckling group and $8.4 \%$ in the control group. The average blood loss in both groups was similar (breast-feeding 258-163 ml, 256-148 ml control group). The results, although based on small numbers, suggest that breastfeeding may be a physiological mechanism beneficial to the mother.

\subsection{Use of Technology}

A study was conducted in Ghana, to evaluate the use of cell phones for reporting PPH data [29]. 10 midwives were trained to send text messages from mobile phones using a simple numeric protocol. The midwives and traditional practitioners were able to use text messaging protocols to inform the clinical results of their rural communities. 425 births were reported during the study period, with PPH occurring in 13 cases $(3.1 \%)$. The results indicate that it is possible to train midwives to use cell phones in order to transmit data related to health, using specific protocols for mobile phones.

\section{Discussion}

PPH remains a major cause of severe maternal morbidity in both low and high resources countries. In countries with lack resources, the most prominent challenges are the lack of qualified health care providers, the insufficient or incorrect practice of active management of the third stage of labor, the underestimation of blood loss and also the impairment in communication and transportation infrastructure. Although the majority of maternal deaths occur in low-income countries, recent publications have shown increased incidence of severe $\mathrm{PPH}$ and its complications in high income countries. The reasons for this increase are unclear. Some authors claim lack of accurate information on cases of PPH in these countries. Confirmation of this trend and possible factors associated with this increase is important for the development of recommendations to address $\mathrm{PPH}$ in future [3].

Active management is considered superior than expectant management in order to prevent PPH and other serious complications in the third stage of labor and it should be routinely implemented for all vaginal deliveries in hospitals, homes and birth centers [32].

Six studies based on AMTSL, included in this review, confirmed that the routine use of AMTSL reduced the incidence of $\mathrm{PPH}$, the amount of blood loss, the need for blood transfusion and additional Uterotonic, and therefore should be included in any intervention program to reduce deaths by $\mathrm{PPH}$, as recommended by [32].

Some findings also confirm the effectiveness of Misoprostol as the choice of Uterotonic in prevention of PPH in rural communities if oxytocin is not available [33]. Some authors [34] evaluated the use of misoprostol at the dosage of $600 \mathrm{mcg}$ for reduction of blood loss and confirmed $11 \%$ reduction of bleeding by placebo and $17 \%$ reduction of hemorrhage with misoprostol. Five included clinical trials showed reduction in postpartum blood loss, and that when administered by a trained midwife can be a viable, safe and effective option for home births. Adverse effects appeared in the following decreasing order of frequency: tremors, chills, fever, nausea, vomiting, diarrhea, headache, weakness, dizziness and fainting.

The estimation of blood loss after birth is very important in diagnosing, controlling and managing PPH. It is very likely that the estimation of the loss of blood can result in error due to lack of knowledge and skill in nurses and other professionals. Accurate visual estimation of blood loss is known to reducing the severity and frequency of PPH. Underestimation may result in inaccurately assessing the situation and increased incidence in PPH.

Bimanual uterine compression is also shown to be efficient in controlling $\mathrm{PPH}$, avoiding a severe hemorrhage with the increased chance of maternal survival [7, 30]. Similarly early breastfeeding was not effective in reducing the frequency of $\mathrm{PPH}$, however, it is concluded that the level of education and knowledge of traditional midwives interfered with the results. They do not put the baby to breast suction immediately after delivery. Breast stimulation causes the uterus to contract, although this mechanism is not yet clear and need to be investigated further.

In case of limited resources, cell phones and other related technologies have shown significant improvement in communication, which can quickly provide the necessary referrals to a distant region. The wide use of those technologies can be very beneficial in the area of health, especially in emergency situations, because it enables quick and correct access to information regardless of the physical location [29].

\section{Conclusions}

This review identified different nursing practices and its various dimensions during and after childbirth, which need to be improved for preventing PPH and deaths of women and 
newborns. PPH complications with the consequent increase in maternal deaths are associated with the lack skilled midwives and birth attendants, lack of resources, inability of health professionals to accurately assess blood loss, delay to decide to get help in obstetric services and delay in referral system and transportation.

The literature highlighted the need for continuing education so that evidence-based practices are applied in the health services. The active management of labor is an intervention that nurses, midwives and TBAs should be empowered to implement in order to reduce $\mathrm{PPH}$ rates. The practice of active management of the third stage of labor substantially shortens the third stage of labor, and so can prioritize nursing care for mother and newborn needs. We also recommend further research into assessing the role and importance of nursing practices in the reduction of PPH and hence maternal morbidity and mortality.

\section{References}

[1] World Health Organization. WHO recommendations for the prevention and treatment of postpartum haemorrhage [Internet] Geneve: WHO; 2012 [cited 2015 Aug 20]. Available from: http://www.who.int/reproductivehealth/publications/maternal_ perinatal_health/9789241548502/en/.

[2] World Health Organization. WHO guidelines for the management of postpartum haemorrhage and retained placenta [Internet]. Geneve: WHO; 2009 [cited 2015 Aug 20]. Available from:

https://books.google.com/books?hl=en\&lr=\&id=val3YtLrgjM C\&pgis $=1$.

[3] Knight M., Callaghan W. M., Berg C., Alexander S., Bouvier-Colle M. H., Ford J.., Joseph K. S., Lewis G., Liston R. M., Roberts C. L., Oats J and Walker J. Trends in postpartum hemorrhage in high resource countries: a review and recommendations from the International Postpartum Hemorrhage Collaborative Group. BMC Pregnancy Childbirth [Internet]. 2009 Nov [cited 2015 Aug 20]; 9 (1): 55. Available from: http://www.biomedcentral.com/1471-2393/9/55.

[4] Souza M. L., Laurenti R., Knobel R., Monticelli M., Brüggemann O. M., Drake E. Mortalidade materna por hemorragia no Brasil. Rev Lat Am Enfermagem. 2013[cited 2015 Aug 20]; 21 (3): 711-8. Available from: http://www.scielo.br/pdf/rlae/v21n3/pt_0104-1169-rlae-21-030711.pdf.

[5] Sheiner E., Sarid L., Levy A., Seidman D. S., Hallak M. Obstetric risk factors and outcome of pregnancies complicated with early postpartum hemorrhage: a population-based study. $J$ Matern Fetal Neonatal Med. 2005 Sep; 18 (3): 149-54.

[6] Karlsson H., Pérez Sanz C. Hemorragia postparto. Anales Sist San Navarra [Internet]. 2009 [cited 2015 Aug 20]; 32 (suppl. 1): 159-67. Available from: http://scielo.isciii.es/pdf/asisna/v32s1/obstetricia6.pdf.

[7] International Confederation of Midwives; International Federation of Gynaecologists and Obstetricians. Joint statement: management of the third stage of labour to prevent post-partum haemorrhage. J Midwifery Womens Health. 2004 Jan-Feb; 49 (1): 76-7.
[8] Leduc D., Senikas V., Lalonde A. B., Ballerman C., Biringer A., Delaney M., Duperron L., Girard J., Jones D., Lee L. S., Shepherd D. and Wilson K. Active management of the third stage of labour: prevention and treatment of postpartum hemorrhage. J Obstet Gynaecol Can [Internet]. 2009 Oct 1 [cited 2015 Jun 20]; 31(10): 980-93. Available from: http://europepmc.org/abstract/med/19941729.

[9] Melnyk B. M., Fineout-Overholt E. Evidence-based practice in nursing \& healthcare: a guide to best practice [Internet]. Lippincott Williams \& Wilkins; 2011 [cited 2015 Aug 20]. 599 p. Available from: https://books.google.com/books?hl=en\&lr=\&id=hHn7ESF1DJ oC\&pgis $=1$.

[10] Bullough C. H., Msuku R. S., Karonde L. Early suckling and postpartum haemorrhage: controlled trial in deliveries by traditional birth attendants. Lancet. 1989 Sep 2; 2 (8662): 522-5.

[11] Bij de Vaate A., Coleman R., Manneh H., Walraven G. Knowledge, attitudes and practices of trained traditional birth attendants in the Gambia in the prevention, recognition and management of postpartum haemorrhage. Midwifery [Internet]. 2002 Mar [cited 2015 Jul 8]; 18 (1): 3-11. Available from: http://www.sciencedirect.com/science/article/pii/S0266613801 90289X.

[12] Glover P. Blood loss at delivery: how accurate is your estimation? Aust Midwifery [Internet]. 2003 Jun [cited 2015 Aug 20]; 16 (2): 21-4. Available from: http://www.sciencedirect.com/science/article/pii/S1031170X0 3800053.

[13] Chandhiok N., Dhillon B. S., Datey S., Mathur A., Saxena N. C. Oral misoprostol for prevention of postpartum hemorrhage by paramedical workers in India. Int J Gynaecol Obstet [Internet]. 2006 Feb [cited 2015 Aug 20]; 92 (2): 170-5. Available from: http://www.sciencedirect.com/science/article/pii/S0020729205 005898 .

[14] Foster J., Regueira Y., Heath A. Decision making by auxiliary nurses to assess postpartum bleeding in a Dominican Republic maternity ward. J Obstet Gynecol Neonatal Nurs [Internet]. 2006 Jan [cited 2015 Aug 20]; 35(6):728-34. Available from: http://www.ncbi.nlm.nih.gov/pubmed/17105637.

[15] Tsu V. D., Mai T. T. P., Nguyen Y. H., Luu H. T. T. Reducing postpartum hemorrhage in Vietnam: assessing the effectiveness of active management of third-stage labor. J Obstet Gynaecol Res [Internet]. 2006 Oct [cited 2015 Aug 20]; 32 (5): 489-96. Available from: http://www.ncbi.nlm.nih.gov/pubmed/16984516.

[16] Buckland S. S., Homer C. S. E. Estimating blood loss after birth: using simulated clinical examples. Women Birth [Internet]. 2007 Jun [cited 2015 Aug 20]; 20 (2): 85-8. Available from: http://www.sciencedirect.com/science/article/pii/S1871519207 000029 .

[17] Hassan-Bitar S., Wick L. Evoking the guardian angel: childbirth care in a Palestinian hospital. Reprod Health Matters [Internet]. 2007 Nov [cited 2015 Aug 20]; 15 (30): 103-13. Available from: http://www.sciencedirect.com/science/article/pii/S0968808007 303212.

[18] Goudar S. S., Chakraborty H., Edlavitch S. A., Naik V. A., Bellad M. B., Patted S. S., Patel A., Moore J., Mc Clure E. M., Hartwell T., Moss N., Derman R. J. and Kodkany B. S. Variation in the postpartum hemorrhage rate in a clinical trial of oral misoprostol. J Matern Fetal Neonatal Med. 2008 Aug [cited 2015 Aug 20]; 21 (8): 559-64. 
[19] Low L. K., Bailey J. M., Sacks E., Medina L., Piñeda H. O. L. Postpartum hemorrhage prevention: a case study in northern rural Honduras. J Midwifery Womens Health [Internet]. 2008 Jan [cited 2015 Aug 20]; 53 (1): e1-6. Available from: http://www.ncbi.nlm.nih.gov/pubmed/18164426.

[20] Prata N., Gessessew A., Abraha A. K., Holston M., Potts M. Prevention of postpartum hemorrhage: options for home births in rural Ethiopia. Afr J Reprod Health. 2009; 13 (2): 87-95.

[21] Sosa C. G., Althabe F., Belizán J. M., Buekens P. Risk factors for postpartum hemorrhage in vaginal deliveries in a Latin-American population. Obstet Gynecol. 2009; 113 (6): 1313-9.

[22] Burke C. Active versus expectant management of the third stage of labor and implementation of a protocol. J Perinat Neonatal Nurs. 2010 Jul-Sep; 24 (3): 215-28.

[23] Edmonds J. K., Hruschka D., Sibley L. M. A comparison of excessive postpartum blood loss estimates among three subgroups of women attending births in Matlab, Bangladesh. $J$ Midwifery Womens Health [Internet]. 2010 Jan [cited 2015 Aug 20]; 55 (4): 378-82. Available from: http://www.pubmedcentral.nih.gov/articlerender.fcgi?artid=28 $97753 \&$ tool $=$ pmcentrez\&rendertype $=$ abstract.

[24] Farrar D., Tuffnell D., Airey R., Duley L. Care during the third stage of labour: a postal survey of UK midwives and obstetricians. BMC Pregnancy Childbirth [Internet]. 2010 Jan [cited 2015 Aug 20]; 10 (1): 23. Available from: $\mathrm{http}: / / w w w . b i o m e d c e n t r a l . c o m / 1471-2393 / 10 / 23$.

[25] Mobeen N., Durocher J., Zuberi N., Jahan N., Blum J., Wasim S., Walraven G. and Hatcher J. Administration of misoprostol by trained traditional birth attendants to prevent postpartum haemorrhage in homebirths in Pakistan: a randomised placebo-controlled trial. BJOG [Internet]. $2011 \mathrm{Feb}$ [cited 2015 Aug 20]; 118(3):353-61. Available from: http://www.pubmedcentral.nih.gov/articlerender.fcgi?artid=30 41931\&tool=pmcentrez\&rendertype $=$ abstract.

[26] Sanghvi H., Ansari N., Prata N. J. V., Gibson H., Ehsan A. T., Smith J. M. Prevention of postpartum hemorrhage at home birth in Afghanistan. Int J Gynaecol Obstet [Internet]. 2010 Mar [cited 2015 Aug 20]; 108(3): 276-81. Available from: http://www.sciencedirect.com/science/article/pii/S0020729209 00650X.

[27] Vivio D., Fullerton J. T., Forman R., Mbewe R. K., Musumali M., Chewe P. M. Integration of the practice of active management of the third stage of labor within training and service implementation programming in Zambia. J Midwifery Womens Health [Internet]. 2010 Jan [cited 2015 May 1]; 55(5): 447-54. Available from: http://www.ncbi.nlm.nih.gov/pubmed/20732666.

[28] Althabe F., Mazzoni A., Cafferata M. L., Gibbons L., Karolinski A., Armbruster D., Buekens P. and Belizán J. M. Using uniject to increase the use of prophylactic oxytocin for management of the third stage of labor in Latin America. Int $J$ Gynaecol Obstet [Internet]. 2011 Aug [cited 2015 Aug 20]; 114(2): 184-9. Available from: http://www.sciencedirect.com/science/article/pii/S0020729211 002621.

[29] Andreatta P., Debpuur D., Danquah A., Perosky J. Using cell phones to collect postpartum hemorrhage outcome data in rural Ghana. Int J Gynaecol Obstet [Internet]. 2011 May 5 [cited 2015 Aug 22]; 113 (2): 148-51. Available from: http://www.ijgo.org/article/S002072921100052X/fulltext.

[30] Andreatta P., Perosky J., Johnson T. R. Two-provider technique for bimanual uterine compression to control postpartum hemorrhage. J Midwifery Womens Health [Internet]. 2012 Jul-Aug [cited 2015 Aug 20]; 57(4): 371-5. Available from: http://www.ncbi.nlm.nih.gov/pubmed/22758359.

[31] Garcia K., Morrison F. B., Savrin C. Teaching guatemala midwives about postpartum hemorrhage. MCN Am J Matern Nurs. 2012 Jan-Feb; 37(1): 42-7.

[32] Prendiville Walter J. P., Elbourne D., McDonald S. J. Active versus expectant management in the third stage of labour [Internet]. Cochrane Database of Systematic Reviews. 2009. Available from: http://onlinelibrary.wiley.com/doi/10.1002/14651858.CD0000 07.pub2/abstract.

[33] Walraven G., Blum J., Dampha Y., Sowe M., Morison L., Winikoff B. and Sloan N. Misoprostol in the management of the third stage of labour in the home delivery setting in rural Gambia: a randomised controlled trial. BJOG [Internet]. 2005 Sep [cited 2015 Jun 12]; 112(9): 1277-83. Available from: http://www.ncbi.nlm.nih.gov/pubmed/16101608.

[34] Høj L., Cardoso P., Nielsen B. B., Hvidman L., Nielsen J., Aaby P. Effect of sublingual misoprostol on severe postpartum haemorrhage in a primary health centre in Guinea-Bissau: randomised double blind clinical trial. BMJ [Internet]. 2005 Oct 1 [cited 2015 Aug 20]; 331 (7519): 723. Available from: http://www.bmj.com/content/331/7519/723.short. 